\title{
Prevalensi Komplikasi Operasi Katarak dengan Teknik Fakoemulsifikasi di Rumah Sakit Family Medical Center Periode Januari-Desember 2016
}

\author{
Silvia Gunawan ${ }^{1}$, Michael Indra Lesmana ${ }^{2}$, Gracia J.M.T Winaktu ${ }^{3}$ \\ ${ }^{1}$ Mahasiswa Fakultas Kedokteran Universitas Kristen Krida Wacana \\ ${ }^{2}$ Staf Pengajar Bagian I.P. Mata, Fakultas Kedokteran Universitas Kristen Krida Wacana \\ ${ }^{3}$ Staf Pengajar Bagian Ilmu Gizi, Fakultas Kedokteran Universitas Kristen Krida Wacana \\ Alamat korespondensi: g_winaktu@yahoo.com
}

\begin{abstract}
Abstrak
Fakoemulsifikasi adalah teknik operasi katarak yang paling sering digunakan. Tujuan dari fakoemulsifikasi adalah untuk memeroleh tajam penglihatan tanpa koreksi dengan waktu sembuh yang cepat serta komplikasi bedah minimal. Akan tetapi, tindakan fakoemulsifikasi dapat menimbulkan komplikasi intraoperasi maupun pascaoperasi. Desain penelitian yang digunakan deskriptif observasional dengan pendekatan retrospektif, yaitu melihat rekam medik pasien periode Januari - Desember 2016. Total sampling sebanyak 165 buah mata yang dioperasi di Rumah Sakit Family Medical Center. Dari hasil penelitian didapatkan lebih banyak penderita perempuan $(53,9 \%)$ daripada laki-laki (46.1\%), dengan rentang usia 40-79 tahun. Komplikasi didapatkan pada 21 mata $(12,7 \%)$ dan tidak mengalami komplikasi 144 buah mata $(87,3 \%)$. Komplikasi intraoperasi yang terjadi, 1 buah mata pada iris adalah traumatik. Komplikasi pascaoperasi yang terjadi adalah 3 buah mata mengalami sindroma mata kering, 5 buah mata mengalami edema kornea, 8 buah mata mengalami sindroma toksik segmen anterior, 1 buah mata mengalami hipertensi okuli, dan 3 buah mata mengalami kekeruhan kapsul posterior. Dari hasil penelitian didapatkan komplikasi tertinggi yaitu sindroma toksik segmen anterior dengan angka kejadian 4,8\% (8 buah mata), dan edema kornea $3,0 \%$ ( 5 buah mata). Sindroma toksik segmen anterior dan edema kornea merupakan komplikasi yang reversibel, membaik dalam 1-2 minggu pascaoperasi.
\end{abstract}

Kata Kunci: katarak, fakoemulsifikasi, komplikasi, sindroma toksik segmen anterior, edema kornea.

\section{Prevalence of Complications after Phacoemulsification at Family Medical Center Hospital during the Period of January-December 2016}

\begin{abstract}
Currently, phacoemulsification is the most commonly used cataract surgery technique. The goal of this procedure is to obtain sharp eyesight without having to do correction procedure with rapid recovery time and minimal surgical complications. However, phacoemulsification procedure can lead to intra- and post-surgery complications. The aim of this study was to determine the prevalence of various phacoemulsification complications. The design used was descriptive observational with retrospective approach. The study was conducted by reviewing patient's medical records of the period of January - December 2016 at Family Medical Center Hospital (total sampling 165 operated eyes). Of all the subjects, there were more females (53.9\%) than males (46.1\%) with age range from 40-79 years. The study indentified 21 cases (12.7\%) wih complications and 144 cases (87.3\%) without complication. Toxic anterior segment syndrome (TASS) was the most reported complication (8 cases), followed by corneal edema (5 cases), dry eye syndrome (3 cases), posterior capsule opacification ( 3 cases), traumatic iris (1 case) and ocular hypertension (1 case). No case of endophthalmitis was reported. This study concludes that TASS was the highest complication with an incidence rate of
\end{abstract}


4.8\%, followed by corneal edema 3.0\%. Both TASS and corneal edema are reversible, which can improve within 1-2 weeks post-surgery.

Keywords: cataract, complication, corneal edema, phacoemulsification, toxic anterior segment syndrome

\section{Pendahuluan}

Mata merupakan salah satu indra yang penting bagi manusia, apabila terjadi gangguan penglihatan yang berat maka dapat mengakibatkan kebutaan. Menurut organisasi kesehatan dunia atau World Health Organization (WHO), sekitar 39\% kebutaan disebabkan oleh katarak. ${ }^{1}$ Katarak berasal dari bahasa Yunani yaitu katarrhakies yang berarti air terjun, dimana dalam bahasa Indonesia disebut bular yang artinya penglihatan seperti tertutup air terjun akibat lensa yang keruh. ${ }^{2}$ Berbagai studi cross sectional menyatakan bahwa angka kejadian katarak pada individu yang berusia 65 sampai 74 tahun sebanyak $50 \%$, dan angka kejadian ini meningkat hingga $70 \%$ pada individu yang berusia di atas 75 tahun. $^{3}$

Sejalan dengan perkembangan ilmu kedokteran dan teknologi, tindakan bedah katarak mengalami perubahan drastis. Saat ini, fakoemulsifikasi adalah teknik operasi katarak yang paling sering digunakan. ${ }^{3}$ Teknik ini menggunakan vibrator ultrasonik genggam untuk menghancurkan nukleus yang keras sehingga substansi nukleus dan korteks dapat diaspirasi melalui suatu insisi berukuran 1,8 $\mathrm{mm}-2,75 \mathrm{~mm} .{ }^{3}$ Ukuran insisi tersebut cukup untuk memasuki lensa intraokular yang dapat dilipat (foldable intraocular lens). ${ }^{3}$ Tindakan operasi untuk pengobatan katarak perlu dilakukan dengan tujuan mengeluarkan atau membersihkan lensa yang keruh sehingga fungsi penglihatan dapat pulih kembali. ${ }^{3}$ Tujuan dari fakoemulsifikasi adalah untuk memeroleh tajam penglihatan tanpa koreksi dengan waktu sembuh yang cepat serta komplikasi bedah yang minimal. ${ }^{2}$ Akan tetapi, tindakan fakoemulsifikasi dapat menimbulkan komplikasi intraoperasi maupun pascaoperasi. ${ }^{3}$

\section{Metodologi Penelitian}

Desain penelitian yang digunakan adalah deskriptif observasional dengan pendekatan retrospektif, yaitu melihat rekam medik pasien yang menjalani operasi katarak dengan teknik fakoemulsifikasi di Rumah Sakit Family Medical Center, Bogor, Jawa Barat dari Januari hingga Desember 2016. Data sekunder dikumpulkan dari Unit Rekam Medik pada bulan Agustus hingga September 2017. Dilakukan total sampling, yang kemudian diseleksi sesuai dengan kriteria inklusi yaitu semua pasien katarak senilis yang dioperasi dengan teknik fakoemulsifikasi dan eksklusi yaitu pasien katarak yang belum dioperasi memunyai penyakit mata lainnya, yang mengalami trauma atau kecelakaan dan yang memunyai riwayat tindakan operasi mata lainnya sebelum operasi katarak.

\section{Hasil Penelitian}

Data sekunder dari Januari sampai Desember 2016 memenuhi kriteria inklusi dan eksklusi, 123 orang pasien dengan 165 buah mata. Komplikasi yang terjadi pada penelitian ini dinilai dari saat operasi sampai satu setengah tahun setelah operasi. Operasi katarak dengan teknik fakoemulsifikasi dilakukan oleh multioperator. Rentang usia yang didapatkan dari data sekunder pada penelitian ini, yaitu 40 hingga 79 tahun. Terdapat 89 pasien perempuan $(53,9 \%)$ dan 76 pasien laki-laki $(46,1 \%)$.

Tabel 1. Jenis Kelamin

\begin{tabular}{ccc}
\hline & \multicolumn{2}{c}{ Frekuensi } \\
\cline { 2 - 3 } & $\mathrm{n}$ & $\%$ \\
\hline Perempuan & 89 & 53,9 \\
Laki-laki & 76 & 46,1 \\
\hline \multicolumn{1}{c}{ Total } & 165 & 100 \\
\hline
\end{tabular}

Tabel 2. Riwayat Penyakit Penyerta

\begin{tabular}{|c|c|c|}
\hline & \multicolumn{2}{|c|}{ Frekuensi } \\
\hline & $\mathrm{n}$ & $\%$ \\
\hline Tidak Ada & 118 & 71,5 \\
\hline Hipertensi & 15 & 9,1 \\
\hline Diabetes Melitus & 20 & 12,1 \\
\hline $\begin{array}{l}\text { Hipertensi dan } \\
\text { Diabetes Melitus }\end{array}$ & 12 & 7,3 \\
\hline Total & 165 & 100 \\
\hline
\end{tabular}


Tabel 3. Diagnosis Pre-Operatif

\begin{tabular}{ccc}
\hline & \multicolumn{2}{c}{ Frekuensi } \\
\cline { 2 - 3 } & $\mathrm{n}$ & $\%$ \\
\hline Katarak Imatur & 84 & 50,9 \\
Katarak Matur & 77 & 46,7 \\
Katarak Hipermatur & 4 & 2,4 \\
\hline Total & 165 & 100,0 \\
\hline
\end{tabular}

Tabel 4. Klasifikasi Komplikasi

\begin{tabular}{ccc}
\hline & \multicolumn{2}{c}{ Frekuensi } \\
\cline { 2 - 3 } & $\mathrm{n}$ & $\%$ \\
\hline Tidak Ada & 144 & 87,3 \\
Komplikasi Intraoperasi & 1 & 0,6 \\
Komplikasi Pascaoperasi & 20 & 12,1 \\
\hline Total & 165 & 100,0 \\
\hline
\end{tabular}

Tabel 5. Jenis Komplikasi

\begin{tabular}{lcc}
\hline & \multicolumn{2}{c}{ Frekuensi } \\
\cline { 2 - 3 } & $\mathrm{n}$ & $\%$ \\
\hline Tidak Ada Komplikasi & 144 & 87,3 \\
Traumatik Iris & 1 & .6 \\
Sindroma Mata Kering & 3 & 1,8 \\
Edema Kornea & 5 & 3,0 \\
Sindroma toxik segmen & 8 & 4,8 \\
anterior & 1 & .6 \\
Hipertensi Okuli & 3 & 1,8 \\
Kekeruhan Kapsul Posterior & 0 & 0 \\
Endoftalmitis & 165 & 100,0 \\
\hline \multicolumn{1}{c}{ Total }
\end{tabular}

Komplikasi tertinggi yang terjadi adalah toxic anterior segment syndrome (TASS) dengan angka kejadian $4,8 \%$ dan edema kornea 3,0\% (5 mata). Sindroma toxik segmen anterior dan edema kornea merupakan komplikasi pascaoperasi katarak yang dapat terjadi dan bersifat reversibel, umumnya membaik dalam 1-2 minggu pascaoperasi.

\section{Pembahasan}

Toxic anterior segment syndrome (TASS) atau sindrom toksik segmen anterior merupakan suatu komplikasi inflamasi segmen anterior yang bersifat akut, steril, dan noninfeksius yang biasa terjadi setelah tindakan operasi segmen anterior, dengan kejadian pascaoperasi katarak yang terbanyak. ${ }^{4}$ Kondisi ini biasanya dimulai dari 12-48 jam setelah operasi, tetapi bisa juga lebih lama, ditandai dengan visus yang buruk dan nyeri ringan. ${ }^{4}$ Pada rapat tahunan yang diselenggarakan oleh American Academy of Ophthalmology pada tahun 2005, 52\% peserta melaporkan telah melihat satu kasus TASS dan 7\% peserta melaporkan telah melihat lebih dari lima kasus TASS. ${ }^{4}$ Menurut penelitian yang dilakukan Choi di Gachon University Gil Medical Center, didapatkan 15 kasus TASS terjadi setelah operasi katarak dengan teknik fakoemulsifikasi selama periode April sampai Desember 2005, dengan lima operator yang berbeda. $^{5}$ Gambaran klinis dan semua kemungkinan penyebabnya diteliti, termasuk cairan irigasi atau obat-obatan, instrumen bedah atau lensa intraokular, teknik sterilisasi untuk instrumen, atau penyakit lain yang menyertainya. ${ }^{5}$ Penyebab terjadinya kasus TASS diduga akibat kurangnya sterilisasi. $^{5}$ American Society of Cataract and Refractive Surgery (ASCRS) telah mengevaluasi kejadian TASS lebih dari satu dekade, ditemukan penyebab tersering terjadinya TASS adalah masalah instrumen pembersihan dan sterilisasi. ${ }^{6}$

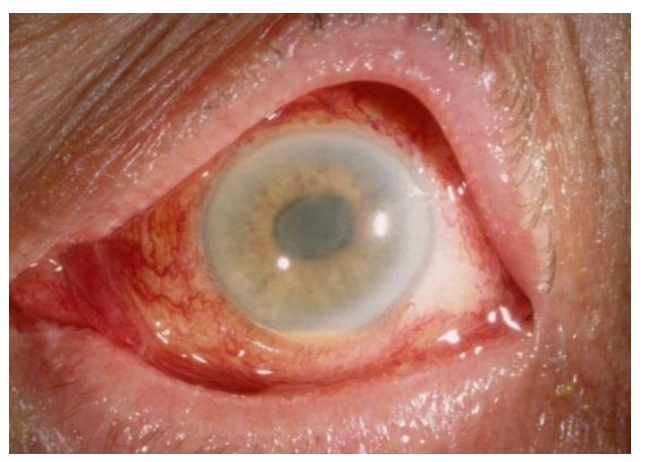

\section{Gambar 1. Toxic Anterior Segment Syndrome ${ }^{4}$}

Komplikasi kedua tertinggi dari penelitian ini, yaitu edema kornea dengan angka kejadian 3,0\%. Edema kornea yang tejadi pada penelitian ini bersifat reversibel, membaik dalam waktu satu minggu dan tidak sampai menimbulkan keratopati. Dari hasil studi yang dilakukan Claesson, sebanyak $43 \%$ pasien mengalami edema kornea persisten segera setelah operasi katarak, faktor risiko utama diduga akibat fakoemulsifikasi dan penyakit endotel yang sudah ada sebelumnya. ${ }^{7}$ Menurut penelitian di Nepal, angka kejadian edema kornea setelah operasi dengan teknik fakoemulsifikasi lebih banyak pada pasien 
diabetes melitus tipe II daripada yang nondiabetes. ${ }^{8}$ Terjadinya dan tingkat keparahan edema kornea setelah fakoemulsifikasi bergantung pada integritas sel endotel kornea. Fungsi sel-sel ini dipengaruhi oleh diabetes melitus. $^{9} \quad$ Berdasarkan penelitian yang dilakukan Marer, Budiman, dan Irfani, faktor risiko yang berhubungan dengan edema kornea dan kehilangan sel endotel kornea selama tindakan fakoemulsifikasi mencakup turbulensi atau pergerakan cairan irigasi, trauma endotel langsung oleh fragmen lensa, dan trauma panas akibat energi ultrasound yang digunakan untuk emulsifikasi nukleus lensa. ${ }^{10}$

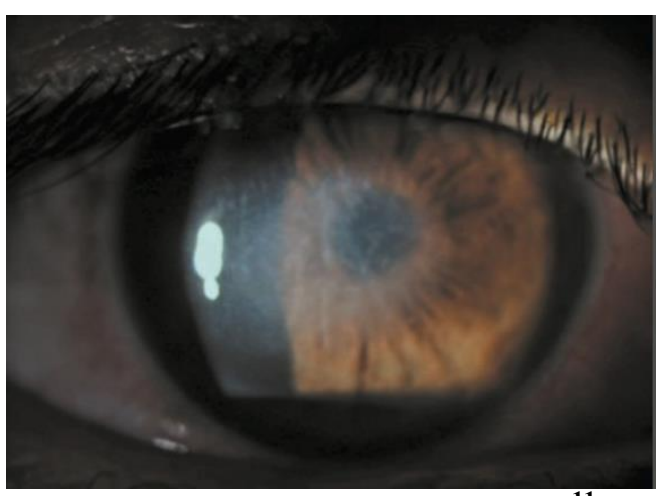

Gambar 2. Edema Kornea ${ }^{11}$

Komplikasi lain dari penelitian ini adalah sindroma mata kering dan kekeruhan kapsul posterior, dengan angka kejadian masing-masing $1,8 \%$. Sindroma mata kering adalah kumpulan dari gangguan pada lapisan air mata yang disebabkan oleh penurunan produksi air mata dan atau peningkatan penguapan air mata, sehingga timbul gejala ketidaknyamanan pada mata. Pada penelitian yang dilakukan oleh Retnaniadi, di poliklinik mata Rumah Sakit Dr. Saiful Anwar, Malang dan Klinik Mata Malang tentang pengaruh jenis insisi operasi katarak terhadap terjadinya sindroma mata kering (SMK), yang mengalami SMK pascaoperasi katarak yaitu 12 sampel $(38,7 \%)$ pada kelompok Extra Capsular Cataract Extraction (ECCE), 11 sampel (35,5\%) pada kelompok fakoemulsifikasi, dan 8 sampel (25,8\%) pada kelompok Small Incision Cataract Surgery (SICS). ${ }^{12}$ Menurut studi di Korea, insisi pada fakoemulsifikasi dapat memicu timbulnya sindroma mata kering pada penderita yang sebelumnya tidak menderita sindroma mata kering. ${ }^{13}$
Kekeruhan kapsul posterior pada penelitian ini terjadi paling cepat dalam waktu 13 bulan pascaoperasi. Pada penelitian ini tidak diteliti mengenai jenis atau material lensa. Pada penelitian di Rumah Sakit Cipto Mangunkusumo tentang insidens posterior capsule opacification (PCO) atau kekeruhan kapsul posterior pada tahun 2010-2013, insidens kumulatif PCO dalam tiga tahun yaitu sebesar $8,82 \%$ (51 buah mata). ${ }^{14}$ Penelitian tersebut dilakukan dengan observasi rekam medis pada 578 buah mata (485 orang pasien) katarak senilis. Katarak terjadi apabila reaksi radang yang diikuti dengan terbentuknya jaringan fibrosis sisa lensa yang tertinggal, maka keadaan ini disebut sebagai katarak sekunder. ${ }^{14}$ Akan tetapi, angka kejadian kekeruhan kapsul posterior semakin menurun dengan teknik fakoemulsifikasi. Penelitian lain terhadap kekeruhan kapsul posterior atau katarak sekunder di RSUD dr. Saiful Anwar, Malang menunjukkan hasil pasien yang mengalami katarak sekunder dengan teknik operasi ECCE sebanyak 68,7\% (11 orang) dan dengan fakoemulsifikasi sebanyak $31,3 \%$ (lima orang). ${ }^{15}$

Komplikasi terendah yang terjadi pada penelitian ini yaitu hipertensi okuli dan traumatik iris dengan angka kejadian masingmasing 0,6\%. Pada penelitian Ilmu Kesahatan Mata Fakultas Kedokteran Universitas Gadjah Mada - RSUP dr. Sardjito terhadap operasi katarak masal dengan menggunakan teknik fakoemulsifikasi dan SICS, angka kejadian tekanan intraokular (TIO) pada SICS sebesar $22,7 \%$, sedangkan pada kelompok fakoemulsifikasi sebesar 4,2\%. ${ }^{16}$

Komplikasi intraoperasi yang berkaitan dengan iris biasanya terjadi karena dilatasi yang tidak maksimal, atau pupil yang mengecil akibat trauma terhadap iris, sehingga memudahkan iris tersedot ke dalam tip fakoemulsi. Hal ini akan menyebabkan konstruksi iris terganggu, terutama akibat lepasnya pigmen yang merupakan kerangka iris. ${ }^{17}$

\section{Simpulan}

Penelitian ini menunjukkan bahwa
operasi katarak menggunakan teknik fakoemulsifikasi di Rumah Sakit Family Medical Center menghasilkan angka kejadian komplikasi sejumlah 21 buah mata (12,7\%) dan yang tidak mengalami komplikasi 
sejumlah 144 buah mata (87,3\%). Dari 21 buah mata yang mengalami komplikasi, satu buah mata mengalami komplikasi intraoperasi dan 20 buah mata mengalami komplikasi pascaoperasi. Dari 165 buah mata yang dioperasi, komplikasi tertinggi yang terjadi yaitu sindroma toksik segmen anterior dengan angka kejadian $4,8 \%$, diikuti dengan edema kornea 3,0\%. Sindroma toksik segmen anterior dan edema kornea merupakan komplikasi yang bersifat reversibel, umumnya membaik dalam 1-2 minggu pascaoperasi.

Hasil dari penelitian ini sesuai dengan penelitian-penelitian yang sudah ada sebelumnya. Operasi katarak dengan teknik fakoemulsifikasi ini memberi beberapa keuntungan, yaitu perbaikan luka yang lebih cepat dengan derajat distorsi kornea yang lebih rendah, keadaan intraoperasi lebih terkendali, menghindari penjahitan, dan mengurangi peradangan intraokular pascaoperasi, sehingga rehabilitasi penglihatan lebih singkat.

\section{Daftar Pustaka}

1. Budiman NK, Knoch AM, Susanti Y. Success rate of phacoemulsification for cataract in patients with high-degree myopia in national eye center Cicendo eye hospital Bandung, Indonesia. Althea Medical Journal 2014;1(1):12-6.

2. Ilyas S, Yulianti SR. Ilmu penyakit mata. Edisi ke-5. Jakarta: Balai Penerbit FKUI; 2014.h.210.

3. Riordan-Eva P, Witcher JP. Vaughan \& Asbury: oftalmologi umum. Edisi ke-17. Jakarta: EGC; 2009.h.169, 175.

4. Al-Ghoul AR. Toxic anterior segment syndrome. 2014. [cited, 2017 March 16]. Available from URL :

http://emedicine.medscape.com/article/11 90343-overview\#a6.

5. Choi JS, Shyn KH. Development of toxic anterior segment syndrome immediately after uneventful phaco surgery. Korean Journal of Ophthalmology 2008;22:2207.

6. Mamalis N. Toxic anterior segment syndrome: Role of enzymatic detergents used in the cleaning of intraocular surgical instruments. J Cataract Refract Surg September 2016;42:84-9.

7. Claesson M, Armitage WJ, Stenevi U. Corneal oedema after cataract surgery: predisposing factors and corneal graft outcome. Acta Ophthalmologica 2009; 87:154-9.

8. Sakhya K, Pokharel S, Karki KJD, Pradhananga C, Pokharel RP, Malla OK. Corneal edema after phacoemulsification surgery in patients with type II diabetes mellitus. Nepal J Ophthalmol 2013;5(10):230-4.

9. Tsaousis KT, Panagiotou DZ, Kostopoulo E. Corneal oedema after phacoemulsification in the early postoperative period: A qualitative comparatives case-control study between diabetics and non-diabetics. Annals of Medicine and Surgery. 2016;5:67-71.

10. Marer E, Budiman, Irfani I. Comparison of corneal endothelial cells loss after phacoemulsification between dispersivecohesive vicoelastic (soft shell) and adaptive vicoelastic in hard density senile cataract. Ophthalmol Ina. 2016;42(1):549.

11. Feinbaum C. New treatment reduces corneal oedema after cataract surgery. 2015.Diunduhdari:http://

ophthalmologytimes.modernmedicine.co $\mathrm{m} /$ ophthalmologytimes/news/newtreatment-reduces-corneal-oedema-aftercataract-surgery?page $=0,1$. Pada 6 Feb 2018

12. Retnaniadi S, Herwindo DP. Pengaruh jenis insisi pada operasi katarak terhadap terjadinya sindroma mata kering. Jurnal Kedokteran Brawijaya Feb 2012; 27(1):34-7.

13. Cho YK, Kim MS. Dry eye after cataract surgery and associated intraoperative risk factors. Korean J Ophthalmol June 2009;23(2):65-73.

14. Ayuningtyas SP, Gondhowiardjo TD. Incidence and associated factors of posterior capsule opacification in pseudophakic patients at Cipto Mangunkusumo Hospital. Med J Indones 2015;24:176-82.

15. Wifaaq $T$. Hubungan antara risiko terjadinya katarak sekunder dengan berbagai teknik operasi katarak di RSUD dr.Saiful Anwar Malang periode Januari Desember 2008. Saintika Medika Des 2015.11(2):85-9.

16. Dibyasakti BA, Suhardjo. Intraocular pressure fluctuation after cataract surgery: comparison between phacoemulsification 
\& small-incision cataract surgery.

Ophthalmol Ina. 2016;42(1):45-9.

17. Soekardi I, Hutauruk JA. Transisi menuju fakoemulsifikasi. Jakarta: Granit; 2004;h.231. 